\title{
Homeobox Protein SIX2
}

National Cancer Institute

\section{Source}

National Cancer Institute. Homeobox Protein SIX2. NCI Thesaurus. Code C111804.

Homeobox protein SIX2 (291 aa, $32 \mathrm{kDa}$ ) is encoded by the human SIX2 gene. This protein is involved in the regulation of transcription. 